18; and 26 per cent, respectively. The decentralization is carried out, in the first place, by creating colleges, institutes or schools attached to the faculties and located so as to avoid overcrowding of students at the present seat of the faculty. At the end of the Fourth Plan, France should have 22 scientific university colleges (of which there are 14 at present in Metropolitan France), 16 arts colleges or institutes, 12 law colleges or institutes; 3 new national institutes of applied science (at Lille, Rennes and Toulouse) and new institutes of political science at Rennes and Lille. A second group of measures will replace a college or an institute by a new faculty; Nice, Rheims, Orsay and Nantes have or are to be given a faculty of science. An increased number of university establishments is contemplated over the whole periphery of the Paris area, including for the sciences extensions of the new Orsay and Quai Saint-Bernard faculties, a third science faculty at Villetaneuse, and three scientific university colleges in the west and east of Paris and at Versailles. A similar tendency to decentralization appears in the projects of the Fourth Plan of Equipment for scientific research so as to provide a better equilibrium between the Paris area and the rest of France. Large scientific groups are expected to be established near some larger towns, for example, for the marine sciences at Brest, Nantes, Toulon and Marseilles; for the land sciences at Nancy; in physics at Rennes and Lannion, and at Grenoble and Toulouse.

\section{British Industry and Automation}

THE first report of the Research and Development Panel, set up in January 1961 by the Executive Committee of the British Conference on Automation and Computation, is entitled Automation and British Industry (Pp. 10. London: British Conference on Automation and Computation, 1963). The Panel concludes that there is considerable scope for the development of new methods of handling light materials, and for some assembly operations production would be more efficient if the parts of the assembly were presented to the operator with the correct rather than random orientation. Greater use of data-processing systems for production planning is recommended, but in most small-batch industries rationalization to give bigger batches would offer major advantages in productivity. The Panel also recommends trade associations and research associations to organize conferences of senior executives within their industries to discuss the use of data-processing equipment, and the associations should, as a matter of urgency, set up teams to assist individual firms in the use of computer centres for production planning, and later, in the light of the sales statistics resulting from these operations, to make recommendations for rationalization within the industries concerned. Facilities for the development of new machines, such as those provided by the National Research Development Corporation and Shirley Development, Ltd., should be extended. It is also felt that arrangements should be worked out to enable capital goods manufacturers to participate in the increased profits resulting from the use of machines they develop, by renting them to manufacturers of the consumer goods. Means should be sought to stimulate backward industries to re-equip with the best foreign equipment available until better British equipment has been developed. Research and development programmes on a national scale should be established for basic problems which occur with minor variations in different industries. Examples of such problems are the control of composition of raw materials, moisture determination, atmospheric control, automatic inspection and assembly, and rapid and economic heating in continuous lehrs.

\section{Government-sponsored Medical Research in Britain}

Is a written answer in the House of Commons on April 30, the Parliamentary Secretary for Science, Mr. D. Freeth, pointing out that the total expenditure on medical research could not be estimated, put Government expenditure in the financial years 1959-60, 1960-61, $1961-62$ and $1962-63$ at about $£ 10.5$ million, $£ 12.5$ million, $£ 14.5$ million and $£ 15.5$ million, respectively. These figures included the estimated expenditure of the Health Departments, Medical Research Council, General Register Office and the Air Ministry and the approximate amount devoted to medical research from general grants to the universities through the University Grants Committee.

\section{Expenditure on the British Advanced Gas-cooled Reactor}

T.N a written answer in the House of Commons on May 6 , the Parliamentary Secretary for Science, Mr. D. Freeth, stated that the Atomic Energy Authority had spent about $£ 10$ million in the development of beryllium as a fuelelement canning material. Of this, about $£ 8.5$ million was spent on cans for the advanced gas-cooled reactor, including the development of techniques and provision of facilities for the manufacture of materials and cans and the production of cans for a part charge for the zero energy facility. Good progress had been made in the development of stainless steel clad fuel elements for the reactor, and a full charge of more than 30,000 cans was now being irradiated. The cost to date of developing the design and manufacturing techniques was estimated at nearly $£ 2$ million.

\section{The British Museum Bill}

When the British Museum Bill was discussed in Committee in the House of Lords on May 6, Lord Chorley, supported by Lord Shackleton and Baroness Wootton, urged that the trustees should not be appointed by the Prime Minister. It was suggested that the trustees should, for the time being, comprise the Minister for Science and individuals appointed by the Treasury on the nomination of the Councils of the Royal Society, the Royal Entomological Society, the Zoological Society, the Linnean Society and the Royal Society of Edinburgh, with three appointed by the present trustees of the British Museum (Natural History). The Earl of Cranbrook and Lord Hurcomb had reservations, and although the Earl of Dundee's reply was not entirely satisfactory to Lord Chorley, the amendment was, by leave, withdrawn. A subsequent amendment by Lord Shackleton, however, providing for the establishment of the National Reference Library of Science and Invention as a separate institution under a separate body of trustees was, however, pressed to a Division and defeated by 39 votes to 23 . Lord Shackleton, claiming that his amendment had the support of the Parliamentary and Scientific Committee in principle and of the Association of Special Libraries and Information Bureaux, was strongly supported by Baroness Wootton and the Earl of Cranbrook and to some extent by Lord Eccles, who thought, nevertheless, that the connexion with the British Museum should remain strong. The Earl of Dundee, replying for the Government, did not accept the arguments to separate the new Library from the British Museum, but his speech added substantially little to what he had said in the earlier debate, and he failed to remove the doubts in the minds of the sponsors of the amendment as to the efficiency with which the needs of science and technology would be met by administering the new Library under one management with the British Museum. In view of the reluctance of the Department of Scientific and Industrial Research to report on its own information services, it is interesting that the Government was defeated on the issue concerning a triennial report of the working of the new Libraries.

Economic and Social Implications of Science and Technology

THE fourth annual inventory of Current Projects on Economic and Social Implications of Science and Technology, 1962, issued by the National Science Foundation, 